\title{
Effects of Quarrying Activities on Environmental Sustainability in Makenene, Centre Region, Cameroon
}

\author{
Gideon Samba* \\ Department of Geography, The University of Bamenda, HTTC, Bambili-Bamenda, Cameroon \\ E-mail: sam_deon@yahoo.fr \\ Reeves Meli Fokeng \\ Department of Geography and Planning, Faculty of Arts, The University of Bamenda, Cameroon \\ E-mail: rfokeng@yahoo.com \\ Julius Tata Nfor \\ Department of Geography and Environmental planning, The University of Dschang, Cameroon \\ E-mail: jtnfor2007@yahoo.com \\ Roland Chah Ngwaimbi \\ Department of Geography and Planning, Faculty of Arts, The University of Bamenda, Cameroon \\ E-mail: cngwaimbi@gmail.com \\ Corine Marcelle Kuache Youogo \\ Department of Geography, The University of Bamenda, HTTC, Bambili-Bamenda, Cameroon \\ E-mail: corineyougo27@yahoo.com
}

\begin{abstract}
Quarrying activities has been regarded as one of the informal activities which has the potential of contributing to the development and economies of communities where ever the quarry companies are installed. But at the same time, the environmental and health impacts of mining on surrounding communities have been a major concern to governments, the general public and stakeholder organizations and individuals. This paper examines the effect of quarrying activities on environmental sustainability of the Makenene community especially at "quartier carrier" in the Center region of Cameroon. To achieve the main aim of the study, three objectives were set to access the environmental impact of quarrying activities on land degradation, water, air and soil quality in Makenene subdivision, examine the effect of quarrying activities on the health of the people of the study area and to appraise the measures which have been put in place for sustainable quarry extraction with focus on environmental sustainability. Purposive and systematic random sampling techniques were used to administer 155 copies of questionnaires drawn from Miller and Brews (2003) sample determination method. Data generated were analyzed using descriptive and inferential statistics. The major findings showed that quarrying activities have significantly affected the "quartier carrier" in Makenene countryside as it has led to environmental degradation, water and air quality distortion. The findings also proved that there have been considerable human health problems resulting from quarrying activities. Based on the findings, the study strongly recommends the government bench of Cameroon to effectively implement its mining/quarry laws and make sure prior Environmental Impact Assessment (EIA), monitoring and evaluation are effective to see that quarry companies operate within the legal frameworks while maintaining environmental sustainability.
\end{abstract}

Keywords: Environmental degradation, Natural resource exploitation, Quarry, Sustainability

DOI: $10.7176 / \mathrm{JEES} / 12-1-03$

Publication date: January $31^{\text {st }} 2022$

\section{Introduction and study area}

There are myriad of problems facing man in the contemporary world. These problems range from economic, political, social, health and environmental, but those arising from environmental degradation have assumed an unprecedented dimension. They include global warming, air pollution, water pollution, land pollution/degradation, acid rain, soil nutrients depletion, climate change, desertification, nuclear accidents, oil spillage, energy crisis and extinction of plant and animal resources. All these problems and many others are conspicuously linked to anthropogenic activities. These anthropogenic activities have been the main architect of the economic, political and social problems facing the world over. One of the anthropogenic activities that have plagued the environment and man, which has also raised some concerns among environmentalists, and other knowledgeable men and women on environmental issues is quarrying activities.

Quarrying in the mining industry is not a new phenomenon (Shrock, 2002) dealing with the effects of quarrying intermediation and its underlying principle is a global phenomenon (Scholtens and Van Wenveen, 2000). 
Virtually, almost all quarrying industries companies did not have the immune to the unprecedented period of economic unrest. It therefore comes as no surprise that quarrying has negative impacts towards the environment which greatly impacted on the economic growth of most nations. Confidence in institutions has been shaken by a series of quarrying collapse and resource exploitation in such quarry plants. Many factors have been put forward as a reason to this, but chief among them is absence of structured process/system of quarrying management (Shrock, 2002).

The economic importance of quarrying activities is enormous, and cannot be overemphasized. Quarrying is necessary to provide much of the materials used in traditional hard flooring, which include granites, limestone, marble, sandstone, slate, clay to make ceramic tiles, and even materials for road construction. Quarrying products have transformed the contemporary world. Many areas have experienced an increase in the infrastructure and mineral resource developments owing to quarrying. As a result, quarrying activities have increased to supply the required construction materials (Mohamed \& Mohamed, 2013). What are worrisome in spite of the economic importance of quarrying activities are the environmental degradation consequences that accompany them. In fact, one wonders whether the benefits of quarrying compensate the implications on the environment and humans.

Cohen (2015) observes that quarrying involves several activities that generate significant amounts of noise. It starts with the preparatory activities, such as establishing road or rail access, compound and even mineral processing facilities. Next is the process of exposing the mineral to be extracted and this is usually done by removing the top soil and other soft layers using a scraper, or hydraulic excavators and dump trucks (Tanko, 2007). The excavation of the mineral itself will involve considerable noise, particularly if blasting methods are used. Following this, the use of powered machinery to transport the materials as well as possibly processing plants to crush and grade the quarry stones all contribute more nuisance to the environment. Cohen further indicated that one of the biggest negative impacts of quarrying on the environment is the damage on biodiversity. Biodiversity essentially refers to the range of living species, including fish, insects, invertebrates, reptiles, birds, mammals, plants, fungi and even micro-organisms. Quarrying carries the potential of destroying these habitats and the species they support. Even if the habitats are not directly removed by excavation, they can be indirectly affected and damaged by environmental impacts such as changes to ground water or surface water that causes some habitats to dry out or others to become flooded.

Again, like many other human activities, quarrying involves the production of significant amounts of waste, (Webster and Fittipaldi, 2007). However, there is still potential for damage to the environment, particularly with water contamination. For example, suspended particles even though they are chemically inert, may imbalance freshwater ecosystems. Large amounts of solids can also exacerbate flooding, if it is dumped on the flood plains (Peters, 1996). In Cameroon, quarrying is a very old industry; the country is currently in the midst of a major shift in the nature of its extractive industries from oil extraction to iron, bauxite, gold, uranium, diamond and other minerals exploitation (Tiffany, 2012). Gravel and building stones quarrying are widespread because they are less capital intensive compared to mineral extraction (Areola, 1991).

Africa has experienced a boom in extractive commodities since about 2000 (Chuhan-Pole et al., 2017). Five to six million people in Africa (20 million in the world) engage in "small-scale mining", often as a side job with farming (Anonymous, 2008). Cameroon is currently in the midst of a major shift in the nature of its extractive industries (Tiffany, 2012). Small-scall quarrying of stone and sand pits is rampant across major river Basins and Highlands of Cameroon. The Sanaga River Basin is well known for its richness in sand, popularly known as the Ebebda sand. Ebebda abounds remarkable sand deposits which supply to all Cameroonians needs, this with the sand coming from the other rivers (Tcheunta and Tagne, 2021). In the Makenene locality in the Centre Region of Cameroon, gravel and building stones quarrying activities have been on-going for decades now. Several processes considered to be damaging to the environment are carried out in the area. These include side preparation (which involves destruction of vegetal cover, clearing and excavation of top soil with heavy machines); drilling of shot holes of several metres using tam rock drillers attached with diamond bits; blasting of the stones with explosives; crushing of rocks to desired pieces as well as into powder by a combination of primary, secondary and tertiary crushers; and screening of the rock chippings and aggregate into different sizes. These processes have had adverse effects on the environment which this research paper sorts to investigate. Several studies on quarry activities brings out its implication on the human environment, (Mohamed and Mohamed 2014; Oguntoke et al., 2009; and Aigbedon and Ayayi 2007). The present study therefore contributes in this same direction by bringing out the case of quarry impact on the environment in Makenene sub-division.

\subsection{Study area}

Makenene is located between latitude 40 52' and 40 55' North of the Equator and between longitude $10048^{\prime}$ and 100 50' East of Greenwich Meridian. The sub-division was created by presidential decree No. 92/127 of June 26, 1992 and covers a surface area of $885 \mathrm{~km}^{2}$. Makenene is distant from Bafia, the head quarter of the division by $100 \mathrm{~km}$ and is bordered to the North by the Municipality of Massangam, to the South by the Yabassi council and Ndikinimeki, to the West by the Municipalities of Deuk and De- Kon Yambeta, and to the East by the Municipality 
of Tonga. (CDP, 2021).

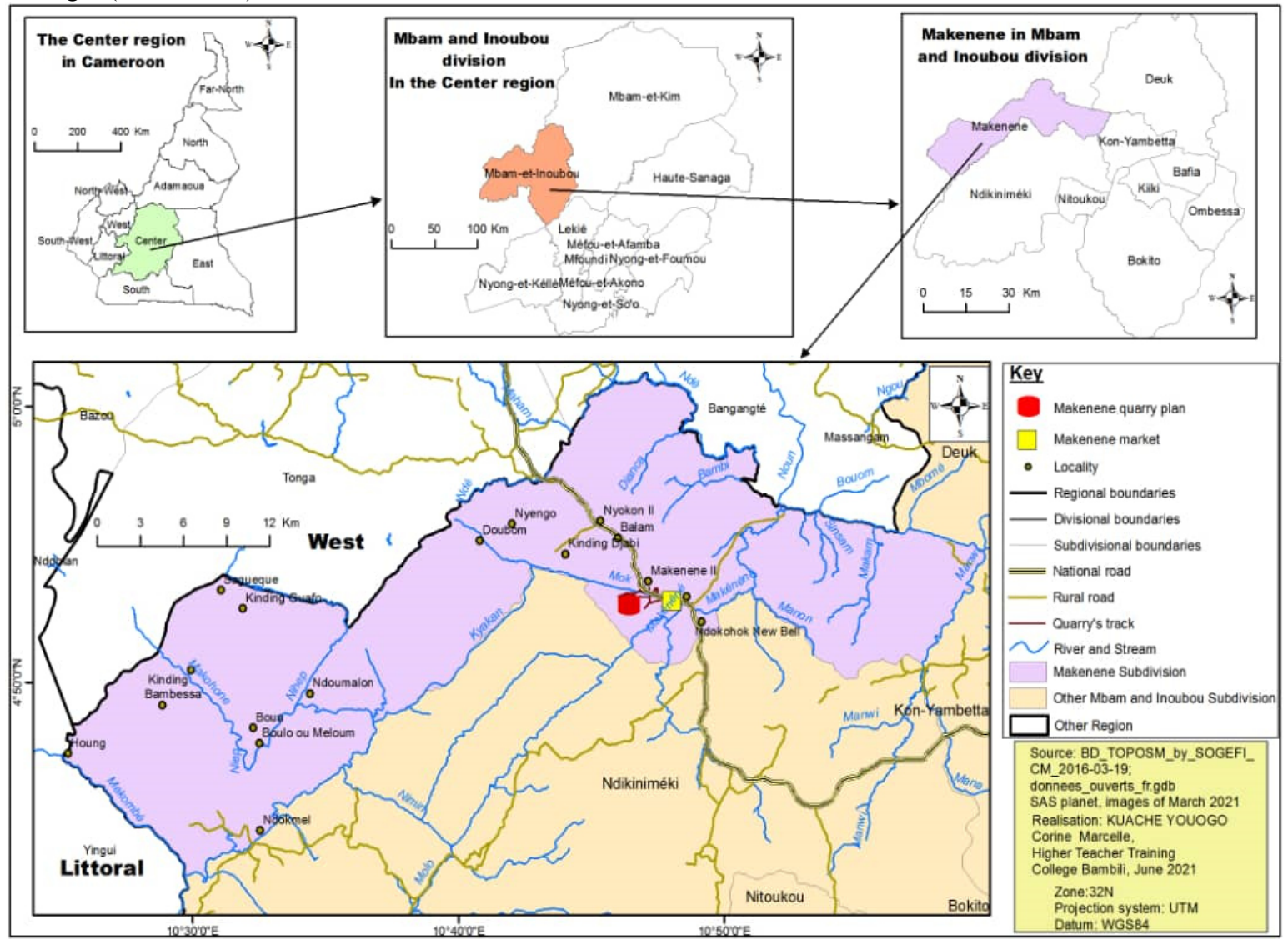

Figure 1: Location of Makenene quarry plan

Source: BD_TOPOSM_by_SOGEFI_CM2016-03-19

\section{Methods}

The study adopts a quantitative and qualitative research design. Primary data included first-hand information generated through the use of both structured and unstructured questionnaire and key informant interviews. Secondary data constituted of text books, journals, public documents, articles, dissertations, census records and a good number of internet websites that were consulted. Purposive and systematic random sampling techniques were used to administer 155 copies of the questionnaire, drawn using Miller and Brewer (2003) sample determination method. Data generated were analyzed using descriptive and inferential statistics. The hypothesis was generated and tested using Pearson Moment correlation test at 0.05 level of significance.

\section{Results and discussions}

Quarrying operations have shown profound consequences on land degradation, water, air and soil quality within extraction zones. Communities around "quartier carrier" suffer most of these adverse effects to the point that some even migrate out of their permanent homes to seek refuge elsewhere. In Makenene, quarrying activities releases significant amount of dust generated through activities such as drilling, blasting, excavation, breaking, stockpiling, conveying and loading. These activities have destroyed the landscape; transform drinking water sources, air and soil quality.

\subsection{Impact of quarry activities on landscape in Makenene}

Environmental effects of surface quarrying are pronounced in Makenene. The findings presented on table 1 reveals that one of the major effects of quarrying activity on land, according to the populations interviewed at the quarry location in Makenene was that quarry activity in Makenene have extensively removed surface soil. This was confirmed by $98.8 \%$ of the population. According to the population, $79.7 \%$ of forested areas in Makenene have largely been cleared for quarry extraction, thus deforestation is rampant at the quarry sites. Most of the inhabitants expressed that trees and vegetation are cleared with heavy machines without replacement thereby depriving the land of its nutrients, and consequently rendering the land infertile for farming. It was observed that there were areas where the land had been covered with rocks and other debris from quarry activities. These have not only impeded growth on the land but has also rendered the surface rugged, making it impossible for farming activities 
to take place.

Table 1: Perception on the effect of quarry on land in Makenene

\begin{tabular}{ccccccccc}
\hline V & \multicolumn{7}{c}{ Frequency (+) } & \multicolumn{7}{c}{ Frequency } \\
\multicolumn{1}{l}{$(-)$}
\end{tabular}

\section{Variables used}

1. Quarry activities have extensively removed top soil

2. Quarry activity have let to extensive deforestation

3. Bare top soils due to quarry activity have intensify soil erosion

4. Rampant soil fertility declined in the study matrix

5. Water sources are drying up in the study area

Note: $\mathrm{SA}=$ Strongly Agreed; $\mathrm{A}=$ Agreed; $\mathrm{D}=$ Disagreed; $\mathrm{SD}=$ Strongly Disagreed

In addition, soil erosion in the area have increased by $94.2 \%$, this explains why the population of Makenene expressed worrisome feelings concerning the future of soil fertility as soil erosion is becoming a major problem of landscape degradation created as a result of quarrying activities, and such areas eventually become inaccessible to the people as they become fatal zones. Field observations confirmed noted that the gradient of some initially gentle slopes in the quarry site have become so steep, while in some areas pits have been created with depths ranging from about 15-30m deep. Even where such pits are backfilled by the company, they are either covered with rocks (which render the land infertile) or are converted into tailings dams where waste and other toxic materials are deposited. Furthermore, table 1 demonstrates that the quarry site at Makenene has witnessed major soil declined in soil fertility; this was confirmed by $91.0 \%$ of the population. This is purely an indicator of land degradation as a result of the quarry activity taking place. The soils have become infertile explaining the reason why most farming activities within a circumference of $2 \mathrm{~km}$ around the quarry sites have been abandoned.

The findings further confirmed that most of the water sources within the vicinity of the quarry plant have dried up leading to serious water scarcity. This has been acknowledged by $96.1 \%$ of the population who further express that even the available streams are polluted causing water crisis to the local inhabitants. According to the local population, the Sino-hydro quarry company exploits their land with a lot of negative consequences given that no adequate sustainable measures have been put in place since the appearance of the first company Ratzel in 2010 . Plate 1 demonstrates some examples of environmental degradation as of the moment the field work was conducted. Field observations disclosed that in the areas where quarrying operation are active, the lands are heavily degraded. Removal of top soils, trees and vegetation with heavy machines deprives the land of its nutrients and renders the land infertile for agricultural.

Figure one on plate 1 shows a large de-vegetated area at the quarry plant, transforming the surface land into deep excavation which can form temporal man-made lakes as in as indicated by plate 1 .

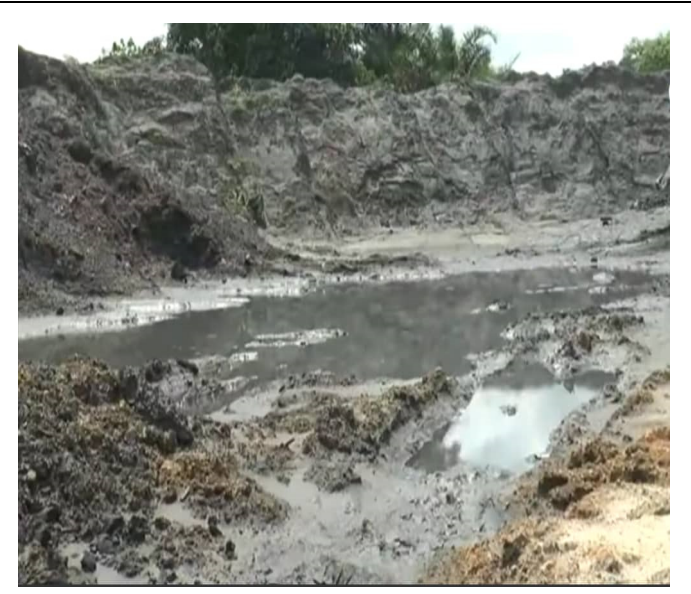

A: Quarry with large de-vegetated land at Makenene

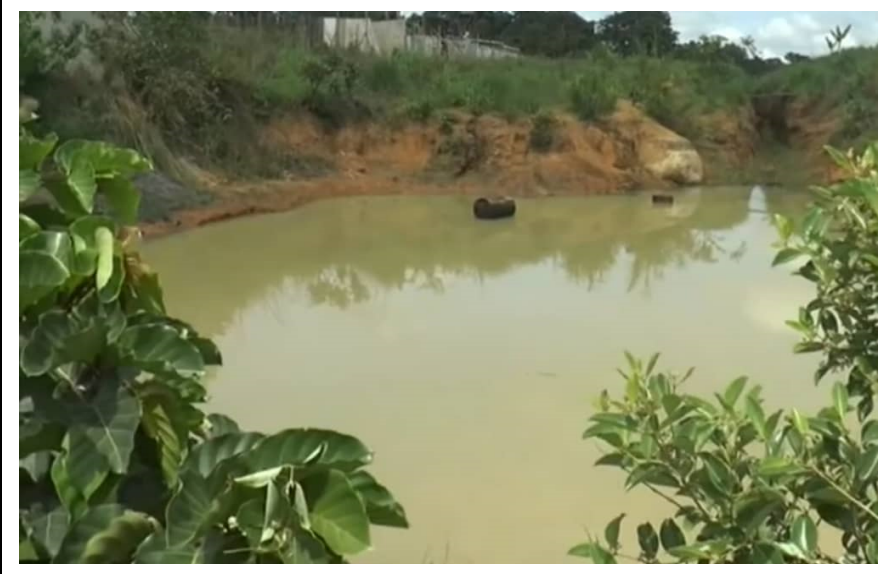

B: Dump quarry site transform into man-made lake in Makenene

Plate 1: Examples of environmental degradation in Makenene

It should be noted that abandoned quarry sites transformed into man-made lake are dangerous spots for 
children as they can get drown in them and people can be killed and thrown into such lake. Moreover, many such quarry pits are left wide opened without any fencing. The quarry sites lack proper fences around their premises and this is very dangerous to the people passing by who can fall into the quarry pit which are more than 15 meters deep.

\subsection{Impact of quarry activities on water resources in Makenene}

Field survey in Makenene community on quarry revealed a worrying issue concerning the impacts of the quarry activity on water resources. It was observed that quarry reduces the water table and sometimes even divert major watercourses away from the quarry site. Water resources in Makenene community are not in a very good state. Most of the streams, rivers and water bodies are either polluted with chemicals or are dried up. Field observation shows that most of the major streams and rivers in the community are polluted by quarry dust. As the situation is now, there are no fishing activities within rivers near the quarries since there are fewer species due to intoxication.

The findings on table 2 shows an overwhelming $93.5 \%$ reaction from the population, indicating that chemical pollution of ground water and streams from quarry plants constitute a major problem for water resources in the study area. The results also pointed that $80.0 \%$ of the stream water at Makenene are affected by water pumped from the quarry field. During the rainy season, water pollution by quarry run-off comprises a big problem for drinking water especially as the streams are filled with quarry debris. This problem was supported by $100.0 \%$ of the sample population. The population further expressed that this quarry run-off causing stream pollution has been going on since the time of the first company IMPRESIT, and during the time of RAZEL and now SINOHYDRO. Leaching causes mineralization in stream sediments; the surface waters often have more or less important concentrations of tin (Tn). The downstream area used by surrounding populations represents a major risk for the development of water borne diseases and many others.

The study further revealed that due to quarry activity, water saltation through increase sediment load in streams and water courses is visible in the study area which greatly distorts water quality. This point was supported by $84.5 \%$ of the sample population in Makenene. Moreover, crops along near the streams are no more eaten by residents due to contamination with cyanide and other toxic chemicals. Although no test was conducted to prove the credibility of the water pollution content, however, it is convincing with the responses from the sample population.

Table 2: Effects of quarry activities on water resources in Makenene

\begin{tabular}{|c|c|c|c|}
\hline Impact of quarry on water resources & $\begin{array}{l}\text { Frequency of } \\
\text { responses }\end{array}$ & $\%$ & Total \\
\hline Chemical pollution of ground water and streams from quarry plants & 145 & $93.5 \%$ & 155 \\
\hline Stream water are affected by water pump from quarry fields & 124 & $80.0 \%$ & 155 \\
\hline Water pollution by quarry run-off & 155 & $100.0 \%$ & 155 \\
\hline Water saltation through increase sediment load from quarry field & 131 & $84.5 \%$ & 155 \\
\hline $\begin{array}{l}\text { Quarry activity interrupt natural water recharge reducing quantity } \\
\text { and quality of drinking water }\end{array}$ & 151 & 97.4 & 155 \\
\hline
\end{tabular}

Most of the visited community members in Makenene acknowledged the fact that they no longer depend on streams for drinking water. Where other water alternatives are inaccessible, residents who depend on streams and other water bodies are at risk of waterborne diseases, and prevalence of diarrhea, typhoid and malaria. The study found out that $97.4 \%$ of quarry activity in the community interrupts natural water recharge, thus reducing the quantity and quality of drinking water. Figure 2 shows how water has been contaminated by toxic chemicals, and due water stagnation, spirogyra is formed. Despite the fact that the streams have been contaminated, the villagers have no other choice than use the water for domestic activities.

\subsection{Impact of quarry activity on vegetation in Makenene}

The environmental impact prediction of quarry activities on vegetation is clearly visible in the study area. The major environmental hazard from the quarry that affects vegetation is dust and this will be dependent on the concentration of the dust particles in the ambient air and its rate of deposition on vegetation especially on the leaves of trees and shrubs around the quarry vicinity. Most of the effects of dust particles on plants include the potential to block and damage the stomata such that photosynthesis and respiration are affected. Other effects are shading (which may lead to a reduction in photosynthetic capacity) wearing down on the leaf surfaces and cuticle. Pollutants such as dust, gaseous emissions and air- borne particulates are produced during quarrying and deposited on plants, disrupting plants from normal functioning, and retarding the process of photosynthesis on vegetation. This no doubt affects the physiological activities of the plants most especially those around the quarry site. The implication of these is that some of the plants may have retarded growth while others may be eliminated. 
$(99.3 \%)$

\begin{tabular}{|c|c|c|c|}
\hline & & (96.1) & \\
\hline & & & (92.3\%) \\
\hline & (87.1\%) & 8 & \\
\hline $\begin{array}{l}\text { Dust particles from } \\
\text { quarry damages plant } \\
\text { stomata }\end{array}$ & $\begin{array}{l}\text { Quarry activities } \\
\text { destroy vegetation }\end{array}$ & $\begin{array}{l}\text { Disruption of } \\
\text { ecosystem } \\
\text { functionality }\end{array}$ & $\begin{array}{l}\text { Photosynthesis action } \\
\text { on palnts is disrupted }\end{array}$ \\
\hline
\end{tabular}

Figure 2: Impact of quarry activities on vegetation

Figure 2 demonstrates reactions from sample the population on the impact of quarry activities nearby vegetation. It shows that $99.3 \%$ of dust particles from quarry plants damages plant stomata, limiting the regulation of gas exchange between the plant and environment and the control of water loss by the plants. It is also noticed that quarrying activities in Makenene destroys vegetation cover by $87.1 \%$. Most of the forest lands in the Makenene have been cleared for quarrying without replacement. This constitutes a major problem in the long term especially as the world is fighting against climate change. The sample population also expressed serious worry at $96.1 \%$, that quarry activities disrupt ecosystem functionality in the study matrix. It is no doubt that the environmental landscape of Makenene have been tampered with, most animal species have disappeared, insects and even some plants species that usually maintain the food chain in the area. It will be difficult to restore the ecosystems of the locality given that semi-desertification is apparently visible within the quarry landscape.

Reactions from population also indicated that due to quarry activity $92.3 \%$ photosynthesis action on plants is disrupted. Dust particles on leaves have blocked stomata hindering the photosynthetic processes. This can explain why most plants are dying out in the study area as one can observe only scanty patches of vegetation.

\subsection{Quarrying impact on soil quality in Makenene}

Excavation and blasting of rocks in Makenene are one of the adverse impacts of quarry, which not only destroys soil structure and changes its properties, but also causes other eco-environmental problems. A four Likert scale agreement level was deployed to sample the perception of the population in Makenene on the effect of quarry activity on the soil quality (Table 3 ). The agreement level was scaled and grouped into positive ( + ) frequency of agree and strongly agree while the negative (-) frequency of disagree and strongly disagree. As indicated on table 3 , the perception of the population showed that quarry crushing activity in the community have caused $81.1 \%$ degradation of soil fertility, $64.5 \%$ soil structure destruction and change in properties, $92.3 \%$ debris dump from crushed rocks, and $61.1 \%$ soil leaching.

$87.1 \%$ of the sample population also pinioned that quarry activity often leads to soil fracture and lots of cracks leading to loss of agricultural land. This usually happened during blasting of rocks and chemical explosive as the earth within few meter circumferences at the site quake, producing cracks and fractures on the nearby soils. It was further revealed that quarry activity has accelerated up to $89.6 \%$ soil water erosion in the Makenene community, a phenomenon very dangerous that can lead to landslide. 
Table 3: Effect of quarry activity on soil quality in Makenene

\begin{tabular}{ccccccccc}
\hline \multicolumn{7}{l}{ Vrequency (+) } & \multicolumn{7}{c}{$\begin{array}{c}\text { Frequency } \\
(-)\end{array}$} \\
\hline SN & SA & A & Total & \% & D & SD & Total & $\%$ \\
1 & 109 & 18 & 127 & 81.9 & 9 & 19 & 28 & 18.1 \\
2 & 31 & 69 & 100 & 64.5 & 6 & 49 & 55 & 35.5 \\
3 & 38 & 105 & 143 & 92.3 & 12 & 00 & 12 & 7.7 \\
4 & 47 & 49 & 96 & 61.9 & 50 & 9 & 59 & 38.1 \\
5 & 37 & 98 & 135 & 87.1 & 20 & 00 & 20 & 12.9 \\
6 & 82 & 57 & 139 & 89.6 & 11 & 5 & 16 & 10.4
\end{tabular}

Variables used

1. Crushing activity cause degradation of soil fertility

2. Quarry activity destroys soil structures and changes it properties

3. Debris dump from crushed rocks affect organic nitrogen content of soil destroying it quality

4. Soil leaching leads to loss of soil texture as top soil is exposed to agent of erosion

5. Quarry activity often lead to soil fracture and lots of cracks leading to loss of agricultural land

6. Quarry accelerate soil water erosion which can lead to landslide

Note: $\mathrm{SA}=$ Strongly Agreed; $\mathrm{A}=$ Agreed; $\mathrm{D}=$ Disagreed; $\mathrm{SD}=$ Strongly Disagreed

\subsection{Test of hypothesis}

This hypothesis was tested to ascertain if there exist any significance effect of quarry activities on land degradation, quality of water and air. The Pearson moment correlation was considered the best tool in testing the hypothesis to check the relationship between the quarry activities and land degradation, water and air quality. From the analysis as presented on table 4 , there exist a perfect correlation between quarry activities and land degradation, water and air quality at a calculated P-value of $.000^{* *}$. The correlation coefficient of quarry activities stands at 1.00 , land degradation, and water and air quality also strongly correlate with quarry activities with the same calculated Pvalue $=.000^{* *}$ (Table 4). The population knowledge and perception present an inversed correlation for urbanization phenomenon at -186 but the calculated P-value was .004 which gave us a good significance. Each of the variables perfectly correlated within itself.

Table 4: Pearson Moment Correlation for quarry effect on land degradation, water and air quality

\begin{tabular}{|l|l|c|c|}
\hline \multicolumn{2}{|l|}{ Variables } & \multicolumn{1}{l}{$\begin{array}{l}\text { Quarry } \\
\text { activity }\end{array}$} & \multicolumn{1}{l}{$\begin{array}{l}\text { Land degradation, water and air } \\
\text { quality }\end{array}$} \\
\hline \multirow{3}{*}{ Quarry activity } & Correlation & 1.000 & .850 \\
\cline { 2 - 4 } & Sig. (1tailed) &. & $.000^{*}$ \\
\cline { 2 - 4 } & df1 & 0 & 209 \\
\hline \multirow{2}{*}{$\begin{array}{l}\text { Land degradation, water and } \\
\text { air quality }\end{array}$} & Correlation & .850 & 1.000 \\
\cline { 2 - 4 } & Sig. (1tailed) & $.000^{*}$ &. \\
\cline { 2 - 4 } & df2 & 209 & 0 \\
\hline
\end{tabular}

Pearson moment correlation coefficient is significant at $0.000 *$ alpha level

For further conformity and clarity, a homogeneity test of the two variances was conducted as presented on table 5. The result gave a P-value of .001 which was not up to the targeted significance level .005. With this result, the researcher rejected the null hypothesis that was stated and upholds the alternative. Therefore, the testing of this hypothesis confirms the finding that quarry activity in Makenene has significantly affected land degradation, water and air quality.

For further conformity and clarity, a homogeneity test of the two variances was conducted as presented on table 5. The result gave a P-value of .001 which was not up to the targeted significance level .005. With this result, the researcher rejected the null hypothesis that was stated and upholds the alternative. Therefore, the testing of this hypothesis confirms the finding that quarry activity in Makenene has significantly affected land degradation, water and air quality.

Table 5: Test of homogeneity of variances of quarry activity on land degradation, water and air quality in Makenene

\begin{tabular}{|l|c|c|c|c|}
\hline Variables & Statistics & df1 & df2 & Sig. \\
\hline Quarry activity & 4.867 & 3 & 196 & $.001^{*}$ \\
\hline Land degradation, water and air quality & 4.717 & 3 & 196 & .001 \\
\hline
\end{tabular}

\section{Conclusion}

Results of this study have proven that quarry activities in Makenene sub-division have caused more harm than good to the community in general. The effects of quarrying on the land, water and air quality have been investigated. 
The findings establishes that quarrying activity in the area has affected the environment by leaving footprints on the surfaces which are not easy to rehabilitate, this has rendered part of the area uneconomical. The test of the hypothesis has corroborated the fact that there exist significant effects of quarry activities on land degradation, water and air quality. Findings from this study shows that, stone quarrying has contributed to land degradation, negatively affected water sources and air quality in Makenene as well as a source of health hazard to the local population. In view of this, small scale stone extraction needs to be recognized by policy makers in relation to individual, household and community benefits. The realization of these efforts will enhance environmental sustainability in the exploitation of this non-renewable natural resource. Hentschel (2003) notes that because informal producers are not supported by mining laws or the legal system in most developing countries, it becomes difficult for informally produced products to penetrate the formal market. As a recommendation, there is need to encourage value added products which fetch more money to strengthen the local or regional market. Recognizing the importance of small-scale quarrying activities will help address the needs of the workers and provision of necessary assistance to prevent hazard mitigation. Legalizing the activities is one of the strategies to reduce environmental degradation.

\section{References}

Aigbedion, I., \& Iyayi, S. E. (2007). Environmental impact of mineral exploitation in Nigeria. International Journal of Physical Sciences, 2 (2), 033-038.

Anonymous (2008). Mineral resources and development in Africa. Strategic guideline document. https://knowledge.uclga.org/IMG/pdf/mineralsresourcesanddevelopmentinafrica.pdf.

Areola, O. (1991). Ecology of Natural Resources in Nigeria. Avebury Academic Publishing Group, Aldershot, England, 178-196.

Chuhan-Pole, P., Dabalen, A.L., Land, B.C. (2017). Mining in Africa: are local communities better off? A copublication of the Agence Française de Développement and the World Bank, International Bank for Reconstruction and Development / The World Bank 1818 H Street NW, Washington, DC 20433.

Cohen, H. (2015). The impact of quarrying; New Delhi: Prentice Hall.

Tcheunta, J.Z., and Tagne, D.R.D. (2021). Production and merchandising of building raw materials in Cameroon: the case of Ebebda sand. Revista de Investigación Multidisciplinaria, 3 (4),18-60.

Hentschel, T., Hruschka, F., and Priester, M. (2002). "Global Report on Artisanal and Small-Scale Mining." Report Commissioned by the Mining, Minerals and Sus-tainable Development of the International Institute for Environment and Devel-opment. DownloadfromHttp://www.Iied.Org/mmsd/mmsd_pdfs/asm_global_report_draft_jan02. Pdf On 20 (08): 2021.

Miller, R. L., \& Brewer, J. D. (2003). A-Z of Social Research. London: Longman.

Mohamed, A. M. and Mohamed, A. E. (2014). Quarry blasts assessment and their environmental impacts on the nearby oil pipelines, southeast of Helwan City, Egypt. NRIAG Journal of Astronomy and Geophysics, 3 (2), 109-210.

Mohamed, A. M. E. and Mohamed, A. E. A. (2013). Quarry blasts assessment and their environmental impacts on the nearby oil pipelines, southeast of Helwan City, Egypt. NRIAG Journal of Astronomy and Geophysics, 2, (1): 102-115.

Oguntoke O.; Aboaba A. and Gbadebo T. (2009). Impact of granite quarrying on the health of workers and nearby residents in Abeokuta Ogun State, Nigeria. Ethiopian Journal of Environmental Studies and Management, 2 (1): $1-11$.

Peters, A. (1996). Acute effects of exposure to high levels of Air pollution in Eastern Europe. American Journal of Epidemiology, 144(6), 570-580.

Tiffany, F. (2012). Extractive industries in Cameroon: A source book for teachers. For UNAFAS Conservation Values Programme, working with RELUFA.

Shrock, D. (2002). Defining Environmental Quality, I.E.Q publication H I. Biennial Report.

Tanko A (2007). "Environmental concerns, assessment and protection procedures for Nigeria's oil industry" Centre for Development studies and the school of Geography, Geol. Environ. Sci., BUK, Nigeria, p. 1.

Webster R.D, Fittipaldi F. (2007). The Interest in Impact Assessment Methods: Environmental Methods Review: Retooling impact assessment for the new century published by Fargo, North Dakota, USA, p. 24. 